\title{
Remembering and Forgetting Winnipeg: Making History on the Strike of 1919
}

Trevor Stace

\begin{abstract}
This article examines the approaches that historians, beginning in the mid 20th century and into the early 21st century, used to write about the Winnipeg General Strike of 1919. It focuses on five major works: The Winnipeg General Strike by D.C. Masters; Confrontation at Winnipeg by David J. Bercuson; The Workers' Revolt in Canada, 1917-1925 edited by Craig Heron; and When the State Trembled: How A.J. Andrews and the Citizens' Committee Broke the Winnipeg General Strike by Tom Mitchell and Reinhold Kramer. It identifies where the monographs depart from one another in interpretation; as well as where they remain the same. Given the layers of complexity, the interpretation of the event becomes especially salient in the 21 st century as its 100th anniversary steadfastly approaches and the question of how should it be publicly presented in 2019 requires an answer soon (which the paper also addresses)
\end{abstract}

With the $100^{\text {th }}$ anniversary of the Winnipeg General Strike of 1919 steadfastly approaching the question of how the representation of the significant Canadian historical event will proceed in the public, the media, and the government [municipally, provincially, and federally] has yet to be answered. The public memory of the Bloody Saturday has endured in the hearts and the minds of Winnipeg-Canadians. In 1969, for instance, on the $50^{\text {th }}$ anniversary of the strike, the United Steelworkers of America presented to the City of Winnipeg a plaque that read: "in honor of the people of Winnipeg whose sacrifices for Union Recognition Helped Millions of Canadians win the benefits of collective bargaining." Twenty-five years later in 1994 , on the strike's $75^{\text {th }}$ anniversary, there were attempts to include its remembrance into official provincial celebrations of Manitoba Day [May 12] — but was ultimately rejected. Ms. Jean Friesen, who represented the electoral district of Wolseley Manitoba, explained that the $125^{\text {th }}$ anniversary of the province's beginning ought be the year's celebrated theme instead. To Friesen, the choice of exclusion represented an "official voice of the past." Efforts for public remembrance continued nonetheless.

In 2009, on the $90^{\text {th }}$ anniversary of Bloody Saturday, The Winnipeg Free Press, provided an exposé on the strike that featured a local historian, Adam Levine, and his point of view. Levine suggested that the strikers were [and still are] "depicted as lawless communists, [as] immigrants denounced as 'bohunks,' ... [who were threatened with] deportation for participating in union activities." "3 To Levine, remnants of the strike, geographical divisions marked in the city, and ideological chasms it created still existed in contemporary Winnipeg when he remarked that "the

\footnotetext{
${ }^{1}$ The Manitoba Historical Society, “Winnipeg General Strike, $50^{\text {th }}$ Anniversary Plaque," Historic Sites of Manitoba: Commemorative Plaques of the Winnipeg City Hall, http://www.mhs.mb.ca/docs/sites/cityhallplaques.shtml [accessed November 2012].

${ }^{22}$ Legislative Assembly of Manitoba, “Thursday May 12, 1994," http://www.gov.mb.ca/legislature/hansard/5th35th/vol_26.html

${ }^{3}$ Anonymous, “The Scars Fade Slowly," Winnipeg Free Press, June 21, 2009, accessed Nov 1, 2012, http://login.ezproxy.library.ualberta.ca/login?url=http://search.proquest.com.login.ezproxy.library.ualberta.ca/docvie w/752229481?accountid $=14474$
} 
quick[est] way to irritate someone raised in Northern Winnipeg is to use the expression 'moving south' to mean crossing a literal bridge from working-class roots to upper-middle-class striving." Official provincial recognition of the Winnipeg General Strike also occurred on the strike's $90^{\text {th }}$ anniversary by way of Hon. Bill Blaikie. On 20 May 2009, the Legislative Assembly of Manitoba received a motion from Blaikie urging the province to "recognize the significant historical contribution of the Winnipeg General Strike in 1919 ... [as a] struggle for social justice." Blaikie stated that the strike was "precipitated by opposition to the principle of collective bargaining, and the need for better wages and working conditions"; even in contemporary society he noted, "there is still opposition to the principle of collective bargaining." With the centennial remembrance of the Winnipeg General Strike of 1919 only five years away, it is curious to imagine the event's public presentation. This is especially fascinating considering scholarly endeavors to evaluate this strike offered from several historians, and whether in any way their accounts will be considered in 2019 for any remembrance or ceremony.

The purpose of this paper is historiographical. It will investigate the scholarly inquiry into the Winnipeg General Strike; identifying not only routes where historians' have departed from one another, but also how they have stayed the same. When analyzing scholarly efforts on the strike from historians writing from the mid $-20^{\text {th }}$ through to the early- $21^{\text {st }}$ century, clearly, different perspectives and narratives emerge. Subsequently, it is important to identify where the features depart from previous works because it demonstrates, over time, scholarly monographs on events in Winnipeg were not constrained to previous generations' interpretations of it. Rather, new perspectives and analyses emerged in the historiography and increased historical understanding on the strike. As such, a significant portion of this historical examination will be in the form of the analysis-section to contrast the monographs' perspectives.

Moreover, just as differences demonstrate the importance of new perspectives, similarities that are found comparing early monographs to later ones highlight important contributions earlier historians made on the general strike. Not only does it show that earlier monographs created fundamental positions on the strike that have withstood later historical examinations into the topic, but also, they allow points of departure that later historians would expand on to add knowledge to Winnipeg General Strike of 1919. Therefore, another major portion of the analysis-section will include an examination into features that carried over from monograph to monograph since the mid-twentieth century. This is particularly important with regard to the Winnipeg General Strike because evidence suggests, in a drive to produce new perspectives from attempts in the late twentieth, and early twenty-first century, there have been some assumptions made that previous monographs had not addressed their new perspectives (though in some cases they did); moreover, to a certain extent, later historical inquiries into the strike have ignored the contributions of early historical works.

In order to facilitate an analysis that addresses the aspects of similarities and departure within the scholarly record of the Winnipeg General Strike, this historiography paper will be divided into two main sections: an [1] overview, followed by [2] an analysis. The overview section will

\footnotetext{
${ }^{4}$ Anonymous, "The Scars Fade Slowly."

${ }^{5}$ University of Winnipeg Faculty Association, " $90^{\text {th }}$ Anniversary of the 1919 Winnipeg General Strike," UWFA News-May 2009, http://www.uwfa.ca/index/2009/5/26/90th-anniversary-of-the-1919-winnipeg-general-strike.html. ${ }^{6}$ Ibid.
} 
review the historical works on an individual basis. A background of each work is necessary to establish before an analysis, because, otherwise the individual contributions of the historians, in this writer's opinion, becomes largely downplayed. Certainly for a scholarly historiography on a topic, historians play an equally noteworthy component than their theories and perspectives that have remained. In this way, allotting a portion of the historiography to particular historians ensures that their contributions will be effectively acknowledged. Moreover, the 'overviewanalysis' feature of the paper provides [at least this writer hopes] a benefit to the reader. The design of the paper facilitates the reader's better sense of understanding where the analysis of this writer originates from; that is, the reader will be prepared to understand the connections made in the analysis. This is particularly important because connections made might seem contentious given an inadequate understanding of features early works had. This may be partly due to assumptions made from later WGS historians who may have possibly downplayed the importance of earlier strike monographs to elevate their own. This point will become clear by the end.

As a general guide to what works to include in the overview section of this paper I have limited the area of focus around those that have been produced by the scholarly community that advanced the historiography through monographs. These include [1] D.C. Masters' The Winnipeg General Strike, published in 1950, [2] David Jay Bercuson's Confrontation at Winnipeg: Labour, Industrial Relations, and the General Strike that was published in 1974, [3] editor Craig Heron's 1998 monograph The Worker's Revolt in Canada, 1917-1925, and finally [4] Reinhold Kramer and Tom Mitchell's When the State Trembled: How A.J Andrews and the Citizen's Committee Broke the Winnipeg General Strike published in 2012. Historian Norman Penner's Winnipeg 1919, published in 1973, is a controversial monograph because the entire monograph, besides the introduction written by Penner, is a reproduction of the striker's view of the history. Moreover, given the context of why it was written, to sell in order to provide funds for the trials of strikers, it lacks certain objectivity. Also, a historiography of the Winnipeg General Strike on the scholarly efforts to the topic ultimately dismisses Winnipeg 1919 since all of the selection, except the introduction, is non-scholarly. With this in mind, Penner's own contribution in the introduction will only be included in the analysis-section of this paper because it provides insight into the trend of scholarly thought that existed, as well as other insights from the historian into the topic. Also, Gerald Friesen's contribution to the historiography of the strike through his essay in River Road: Essays on Manitoba and Prairie History will also be embedded in the paper but not in the overview-section because, as an essay, there is not have enough content to warrant an exposé into the topic compared to the historical works that are included. As such, Friesen's contribution will also be placed in the analysissection and contextualized within the historiography as literature that expanded on a point made by one of the major historians on the topic, D.C. Masters.

\section{D.C Masters: A Seminal Strike Study}

In 1950, D.C. Masters, then-Professor of History at Bishop's University jumpstarted the scholarly communities interest in the strike with The Winnipeg General Strike. Part of his analysis examines what elements ultimately fostered the strike. One general feature of all the elements examines is that they occurred after the year 1914; prior to 1914 there were little elements to be found in Masters' perspective. The post-1914 city of Winnipeg is when the working class within the city became increasingly active. He finds that, prior to 1914 that the 
"trade union movement ... had remained comparatively mild an orthodox."7 To this end, Master's does not go any further in identifying features of Winnipeg predating 1914; instead, he focuses on events after. Masters identifies the year 1918 as key to a development of worker militancy and western radical labour ideology that would spawn the strike. Generally, Masters develops the entire monograph primarily based off of newspapers written in Winnipeg during this time: the Western Labor News - published by the Winnipeg Trades and Labour Council that was pro-striker, and the Citizen — a newspaper published by the Citizens' Committee of $1000{ }^{8}$

In Winnipeg, Masters finds that the Fowler amendment, enacted by the city to combat the legitimacy of a civic employee's legality to strike, showed the lengths the city's council was willing to put themselves at odds with workers. ${ }^{9}$ When the federal government, by way of Gideon Robinson, intervened, supported the workers and recommended the Fowler amendment be scrapped, the working class legitimacy to hold a general strike, and the positive results of a general strike were remembered the following year. ${ }^{10}$

Another crucial 1918-event Masters identifies that led to the Winnipeg General Strike of 1919 was the Walker Theatre event on 22 December 1918. Here, worker militancy, consisting of a range of ethnic workers - which showed the sphere of influence of worker solidarity superseded ethnic concerns, was vigorously advocated and key individuals who would play a significant role in the general strike of 1919, like, Bob Russell — a British radical— in particular, attended. ${ }^{11}$

Masters finds influences from outside the city too. For instance the Seattle General Strike of 1918, due of the similarities like using placards allowing milk and bread deliveries, influenced to the strike leaders in Winnipeg. In Master's opinion, it provided a basis to strategize an organized general strike that maintained the services of society. Nationally, Masters finds that post-war inflation was a factor to the strike when he reviews the trials of individuals following the strike; as well as a growing communist-fear in Canada as a result of occurrences in the United States that centralized on this feature. ${ }^{12}$

Masters largely ignores events of 1919 that immediately preceded the strike later that year; with one exception. Master's treated the One Big Union (OBU) and their advocacy of worker militancy as ideologically influential for the city's strike. ${ }^{13}$ Masters also determines that main reason for the citywide strike in 1919 was because of the construction and metal trades. They struck for two reasons which established numerous sympathy strikes: the right to bargain collectively, and the right to work for a living wage. ${ }^{14}$ Also, he examines the non-violent, organized atmosphere that workers were trying to establish within the city, as well as the strike

\footnotetext{
${ }^{7}$ D.C. Masters, The Winnipeg General Strike [Toronto: University of Toronto Press, 1950], 5.

${ }^{8}$ The Manitoba Historical Society, "Timelinks: The Western Labour News,"

http://www.mhs.mb.ca/docs/features/timelinks/reference/db0063.shtml [accessed November 2012].

${ }^{9}$ Masters, The Winnipeg General Strike, 13-14.

${ }^{10}$ Ibid.

${ }^{11}$ Ibid, 5, 18, 36.

${ }^{12}$ Ibid, 46, 62-63, 75.

${ }^{13}$ Ibid, 21-30.

14 Ibid, 49.
} 
leaders' attempts to harness the influence of returning army veterans to their cause - ultimately unsuccessful due to the division in attitude of the war veterans concerning the strike. ${ }^{15}$

Contrastingly, he briefly identifies and considers the strikers opponents in the ordeal, the Citizens' Committee of 1000 and the Dominion government. He finds the committee was legitimately alarmed at the strike; that they were neutral and mild initially; and only advocated and enforced increasingly drastic measures towards the end to pacify the striking workers. The anti-striker group had a newspaper, The Citizen, which Master's takes at face value showing their threat of communism and the fear of non-strikers in the city. ${ }^{16}$ Masters' perspective on the Dominion government's reaction to the Winnipeg General Strike is another theme of The Winnipeg General Strike - and we will see that this is an important facet to consider regarding the historiography on the strike that proceeds the historian. For Masters, Arthur Meighen took the lead for the government in attending to the situation and was responsible for extreme measures taken like the amending the Immigration Act in order to facilitate the deportment of radical strikers when possible. ${ }^{17}$

Masters finalizes his monograph by identifying the consequences that resulted following the strike both in the short-term and long-term; also he provides interpretation on the notion of whether the strike was a revolution [he didn't think it was revolution because of missing variables like armament]. ${ }^{18}$ In the short-term, he focuses on the martyrdom of the strike leaders that followed the strike in working class community, like Russell [who, interestingly, opposed the strike yet became integral in it nonetheless] and J.S Woodsworth. ${ }^{19}$ In the long-term, he identifies the general strike's effect on legislation introduced in Canada. Section 98 was amended to include the prohibition of unlawful assembly; and Section 138, which dealt with issues of freedom of speech, was repealed. ${ }^{20}$ Controversially, he questions the legitimacy of the fame Woodsworth received following the strike considering the role he actually played in it. ${ }^{21}$ Finally, while he provides an analysis that refutes the idea that played out in courts, that is, the strike was an attempt at a revolution, he acknowledges that the strike "greatly hastened the readiness of Canadians to accept modifications of a laissez-faire policy" towards the economy. ${ }^{22}$ The next academic attempt at interpreting the events of the Winnipeg General Strike of 1919 occurred about twenty-five years later by David Jay Bercuson in 1974.

\section{Bercuson's Confrontational Winnipeg}

David J. Bercuson finds that the Winnipeg General Strike was a culmination of a variety of issues that existed in the city of Winnipeg. Some of these were unresolved issues that dated back to the beginnings of Winnipeg as an industrial town. With the rapid growth of Winnipeg as an industrial city, Bercuson finds that it revealed problems like poverty, and the inability for the city

\footnotetext{
${ }^{15}$ Ibid, 47, 50, 60-61,

${ }^{16}$ Ibid, 66-68.

${ }^{17}$ Ibid, 103, 106.

${ }^{18}$ In practically all the later works the notion of whether or not attempts at a revolution occurred in Winnipeg in 1919 have been commented on by practically all historians. Unanimously they all agree that a revolution didn't occur. The fact that Masters also determines this, without access to as many documents is noteworthy.

${ }^{19}$ Masters, Winnipeg General Strike, 113, 130-131.

${ }^{20}$ Ibid, 138 .

21150 .

${ }^{22}$ Ibid.
} 
to keep up to the burgeoning influx in population; within industry, victimization of unorganized workers occurred. ${ }^{23}$ When workers did organize enough to strike, employers' legal right to file for injunctions against strikes, such as the 1906 worker's dispute with Vulcan Iron Works metal company, resulted in worker sentiment that they could not rely on their government or courts to acknowledge their grievances. $^{24}$

Bercuson identifies post-1913 as playing a large contributing factor to the general strike of 1919 too. Bercuson provides an exposé into the economic recession that preceded the Great War. For Bercuson, the depression [caused by international factors] marginalized the working class to utter dismay, finding evidence such as ninety per cent unemployment in some areas of trade, and practically the disappearance of a construction industry in Winnipeg. ${ }^{25}$

The Great War, to Bercuson, also brought governmental intervention to Winnipeg that ultimately gave way to the general strike; these include both federal and provincial stipulations. ${ }^{26}$ When inflation occurred in the economy, he finds federal intervention into the economy resulted in little improvement in the relationship between the rising cost of living and the worker's pay. ${ }^{27}$ Moreover, an unequal wage for workers within shops contracted by the federal government to supply war material gave rise to unions who fought for "men who ... [were] all doing the same class of work" but received less pay than fellow shop workers; also, the federal government's ideologically oppositional stance to unionism, by way of Joseph Flavelle, and its adherence to a status-quo treatment of munitions production across Canada facilitated increasing discontent with workers and their place in society. ${ }^{28}$ Another feature that contributed to the worker strife in Winnipeg, Bercuson suggests, was fear of industrial conscription in Canada as a result of the Borden government's national registry. ${ }^{29}$ Also, Orders-in-Council implemented during the war, which explicitly subordinated the working class by disallowing strikes or lockouts, and provided enough ambiguity to the responsibility of the employers to allow unfair treatment to workers and fostered resentment in Winnipeg. ${ }^{30}$

Provincially, Bercuson largely perceives the Norris government that provided legislation in hopes of balancing the power between employers and employees as "timid;" for instance, the power of Fair Wage Act of 1916 functioned only in provincial work projects thus bypassing large sectors of the provincial economy. ${ }^{31}$ Moreover, employers who were provincially contracted paid the provincially stipulated wages to only employees who were physically on the work sites; any work done by employees on company locations, even if what they were doing related specifically to the provincial contract, were subject to employer-appointed wages. ${ }^{32}$ In the case of women in the workforce, the Norris government drafted legislation towards a minimum wage for women dependent on what industry they worked in; but it was not without controversy.

\footnotetext{
${ }^{23}$ David Jay Bercuson, Confrontation at Winnipeg: Labour, Industrial Relations, and the General Strike [Montreal and London: McGill-Queen's University Press, 1974], 20.

${ }^{24}$ Ibid, 15, [also find more evidence of this in the pages]

${ }^{25}$ Ibid, 22-23, 26.

26 Ibid, 33.

27 Ibid, 35.

${ }^{28}$ Ibid, 36-38.

${ }^{29}$ Ibid, 41.

${ }^{30}$ Ibid, 82-83.

${ }^{31}$ Ibid, 47-48.

32 Ibid.
} 
The Winnipeg Trades Council [WTC] advocated that instead for a "blanket minimum of ten dollars" would be better for their workers. Although a cogent argument from the Norris government was given for the decision to not legislate a blanket minimum the point that the provincial government was dictating the terms of engagement of the employee into the economy without advisement was not lost on workers or the WTC. ${ }^{33}$

The consolidation of industrial economic power in the city was evident. In particular, the attitudes towards employees of two particular owners, to Bercuson, contributed to the militant display in Winnipeg, that is, the general strike of 1919, and a fundamental reason for the strike occurring in the Winnipeg and not other cities in Canada. Specifically, the companies Manitoba Iron Works, and Vulcan Iron Works owned by, respectively, Thomas Russell Deacon and the Barrett Brothers had anti-union attitudes and did not receive unionists, or union leaders, well. Bercuson discovers that the Barrett brother's, who had won a key victory in Winnipeg against labour in 1906 which resulted in removing unions in any form from their company, constantly refused to acknowledge the legitimacy of the role of unions in their company or industry; whereas Deacon was anti-union on principle because he believed it produced stagnation in the individual and inherently "capitalism stimulated individual initiative."

Soon these factors, alongside the perceived general lack of western labour representation, and, specifically, Winnipeg representation, in the workers national body of assembly, the Trades and Labour Congress of Canada, resulted in increased worker radicalism in the city. ${ }^{35}$ Moreover, as the popularity of socialism came about — partly due to the knowledge that working-class revolutions were "toppling governments from Petrograd to Berlin," and the popularity of the general strike tactic increased due to successful results in Winnipeg in 1918 and from "Scandinavia to Seattle" the Winnipeg General Strike materialized on May 15, 1919. When the construction and metal trades struck and spawned sympathy strikes in Winnipeg, the factors, to Bercuson had to do with a variety of levels, from the micro-level, on the floor of the work place, to the relationship workers had with specific owners, to the treatment of City officials to workers, to the provincial level that was ineffective, to a macro-level and the treatment of workers by the Dominion government. ${ }^{36}$ Twenty years later, Craig Heron building upon a macro-level perspective of the Winnipeg general strike edits Workers Revolt in Canada that fundamentally established the Great War as ultimate cause for revolts in Canada, Winnipeg included.

\section{Heron's Winnipeg: The Strike as a Function of the Great War}

One of the major components of Heron's perspective on why the Winnipeg General strike occurred is the Great War. ${ }^{37}$ Heron deemphasizes the period before the war because he surmises that this period reflected a Canada that soon became practically unrecognizable in comparison to the period during and after. ${ }^{38}$ Pre-1914, the workers were a fragmented group yet the common

\footnotetext{
${ }^{33}$ Ibid, 49-50.

${ }^{34}$ Ibid, 52.

${ }^{35}$ Ibid, 59-77.

${ }^{36}$ Ibid, 89.

${ }^{37}$ Craig Heron, ed., The Workers' Revolt in Canada, 1917-1925 [Toronto, Buffalo, and London: University of Toronto Press, 1998], 11.

${ }^{38}$ Ibid, 18.
} 
experiences felt due to the Great War ushered in a new type of discontent. ${ }^{39}$ The Great War's effect impacted the working class across the entire country because it significantly altered the way that the state interacted with the economy. To Heron:

The First World War ... disrupted the dynamics of pre-war working-class life and provided new pressures and opportunities that would fuel large-scale working class organization, resistance, and radicalization across the country. ${ }^{40}$

Generally, the war resulted in two particular effects, capital injections into the economy, and the Canadian Government expanding its "traditional limited role" in economic regulation. This created a set of circumstances that fostered growth in the working class consciousness. ${ }^{41}$ Specifically, the consciousness soon resulted in the public perspective that wartime profiteering was occurring, and the Canadian Government began to carry features of a corporate state. ${ }^{42}$ By 1916, initial effects of an injection of capital into the economy resulted in a balance of power in industrial relations that had not existed before within Canada. ${ }^{43}$ According to Heron, power, to a certain extent, swayed to the workers because increased employment opportunities meant that workers became a valued commodity and could dictate better terms of engagement into the economy. However, the 'taste' of economic power didn't last long when in 1917 inflation in the economy prevailed and placed the workers in circumstances that profoundly affected their power in the economy, and reduced their pay's ability to sustain an adequate standard of life. ${ }^{44}$ Soon public anger was directed towards the system of capitalism because they perceived owners of industry were not engaging in self-sacrifice like workers and instead profiteered off the war. ${ }^{45}$ 1917, was a penultimate year in Heron's analysis for other reasons too.

1917 ushered in the return of war veterans who, for a variety of factors, became vocal against a sense of injustice within the country. ${ }^{46}$ There was a perception that the Canadian state was becoming increasingly dictatorial in issuing the terms of worker engagement into the economy without allowing any advancement in workers' rights. ${ }^{47}$ As such, the Trades and Labour Congress of Canada, the national voice of the worker, became increasingly ineffective. ${ }^{48}$ Alongside these features of Canadian society was the knowledge of a worker revolution occurring in Russia and soon popularized the idea of socialism in some areas of the Canadian population too. By 1918, the militancy of the worker was felt across Canada and because incidences of national strikes, like the letter carriers strike, the government was inclined to suspect that worker discontent could yield a worker revolution. ${ }^{49}$

While Winnipeg during this time was an interesting case study given the general strike of 1919, Heron suggests that in the past, studies have overemphasized this region in Canadian history and

\footnotetext{
${ }^{39}$ Ibid.

40 Ibid, 11.

${ }^{41}$ Ibid, 12-14.

42 Ibid, 15.

43 Ibid, 19.

${ }^{44}$ Ibid, 22.

45 Ibid, 25.

${ }^{46}$ Ibid, 23.

47 Ibid, 33.

${ }^{48}$ Ibid, 29-30.

${ }^{49}$ Ibid, 181.
} 
led to an inaccurate analysis that associated the strike in terms of a demonstration of a regional western discontent. ${ }^{50}$ When reviewing the history of workers across Canada, from the Maritimes, Northern Ontario, Quebec, and British Columbia in the time period Heron finds that a working class consciousness existed, and manifested in different ways due to their region. ${ }^{51}$ The history of Winnipeg has been implemented improperly as a yardstick to measure the magnitude of working class revolts elsewhere in Canada to the detriment of masking a national working class revolt in history. This affected the lack of recognition in Canada about the history of the nation-wide worker protest for some time. Only since 1983, with the historian Gregory Kealey's address to the historical community that there was a definite pattern in rhetoric of working class discontent at the capitalist system across Canada has there been interest from scholars of a nation-wide occurrence of a working class consciousness as a result of the Great War. ${ }^{52}$ Instead of the Winnipeg General Strike being perceived as nuance in Canadian society Heron seeks to establish the perspective that the manifestation within Winnipeg was, fundamentally, a result of the new working world that workers found themselves in as a result of the Great War. Other features that the Winnipeg General Strike dismissed far too quickly in the past were focuses on ethnicity, gender and whether the strike was political or not. ${ }^{53}$ Through historians Tom Mitchell and James Naylor, Workers Revolt in Canada, 1917-1925 provides an analysis of the Winnipeg General Strike of 1919.

Nationally, the impact of the Winnipeg's general strike had one significant feature for Mitchell and Naylor, they wrote that the general strike ultimately affected the "social relations and the Canadian state" after the strike ended. ${ }^{54}$ In this perspective, the relationship that the strike had in the political realm is examined; however, like WGS historians who preceded them, they write that the strike wasn't political in the sense that is was not constructed as a device to overthrow the established order. ${ }^{55}$ Instead, the political effect of the strike trickled down in the following years and resulted in an increased consideration of the relationship between the workers and the state by the government.

Generally, since the events leading up to the strike had been articulated by Heron in the introduction, the chapter entitled 'The Prairies: In the Eye of the Storm,' provides only an overview of the events during the strike - a narrative that has been thoroughly investigated by Bercuson previously. ${ }^{56}$ However, one feature that the narrative of the events provides, though brief, is an examination of how women and ethnic-categories fit more into the scope of WGS. ${ }^{57}$ What is most significant about this newer attempt at the history of the strike is Mitchell and Naylor's inclusion of a 'top-to-bottom' approach. ${ }^{58}$

Previous to this, undertakings from the historians tended to largely ignore this aspect, or simply 'tacked' it on as a feature to the narrative of the WGS rather than being the story itself, and to

\footnotetext{
${ }^{50}$ Ibid, 4.

${ }^{51}$ Ibid, 8; also, the chapter's titles show Heron's perspective as far as what regions should be included in a national analysis of worker discontent.

52 Ibid, 5.

${ }^{53}$ Ibid, 6-7.

${ }^{54}$ Ibid, 176.

${ }^{55}$ Ibid, 180.

${ }^{56}$ See Burcuson's Confrontation at Winnipeg, 115-162.

${ }^{57}$ Heron, Workers' Revolt in Canada, 185.

${ }^{58}$ Ibid, 203.
} 
some extent, Mitchell and Naylor are equally guilty of this in their chapter in Workers' Revolt in Canada. Forgivingly, on the whole, the 'top-to-bottom' approach receives little attention by Mitchell and Naylor understandably due to the large breadth of topic, 'working class revolt on the Prairies,' they were tasked with writing about in Workers' Revolt in Canada. However, given the monograph on the Winnipeg General Strike that Mitchell, along with historian Reinhold Kramer, produced entitled When the State Trembled: How A.J Andrews and the Citizens' Committee Broke the Winnipeg General Strike later released in 2010, which incorporates a 'topto-bottom' perspective as the major theme, we see that Mitchell follows up his brief examination into the strike in these terms with an in-depth monograph.

\section{Mitchell and Kramer's History of the Strike from Above}

Mitchell and Kramer's narrative of the strike in Winnipeg strike stays exclusive in their content. Instead of centralizing on the activities of the strikers, the two note a de-emphasis occurring in the historiography that largely ignored the Citizens Committee of 1000 [CC1000] and their function in the strike - especially given their success. ${ }^{59}$ Earlier historians have accounted for the CC1000 but on the whole relegated their role to the periphery. Specifically, the significant emphasis of When the State Trembled is a function of documents that became available to the public in 1987 that showcased the role Winnipeg-lawyer A.J Andrews played during the general strike. ${ }^{60}$ Mitchell and Kramer emphasize they aren't seeking to defend the actions that were taken by Andrews and the CC1000. ${ }^{61}$ Instead, finding inspiration in Lineages of the Absolutist State writer Perry Anderson who suggested "a history from above ... in no less essential than a ... history from below," seek to detail the CC1000's actions. ${ }^{62}$ When viewed from this perspective, it is a top-to-bottom approach to the Winnipeg General Strike that highlights the daily issues for the CC1000 from when the strike began to its final end. Yet, when we consider for a moment the significant role that A.J. Andrews played at the micro-level in Winnipeg, and the division between Andrews and the federal government, perhaps the perspective Mitchell and Kramer establish in When the State Trembled is better defined rather as 'middle-to-top-tobottom'- this will soon become evident.

Mitchell and Kramer, as a sub-theme, begin by suggesting that during this period, in Canada there was legitimate concern from the Government that revolution was 'in the air' internationally, but nationally also. ${ }^{63}$ When the strike occurred, Mitchell and Kramer find that the CC1000, generally, engaged in a vast amount of propaganda to undermine grievances of the Winnipeg-worker; specifically, the committee used the fear of bolshevism, deprivation to the necessities of life, and of 'enemy' aliens to establish the image that the workers were unjust. ${ }^{64}$ Moreover, practically every action of the workers was twisted so as to give the appearance of a body of men that were immoral in nature and "anti-society." 65 The CC1000 also downplayed the efforts of the strikers, suggesting that the strikers were looking for a simple way to become

\footnotetext{
${ }^{59}$ Tom Mitchell and Reinhold Kramer, When the State Trembled: How A.J Andrews and the Citizens' Committee Broke the Winnipeg General Strike [Toronto, Buffalo, and London: University of Toronto Press, 2010], 3,6.

${ }^{60}$ Ibid, 39-40.

${ }^{61}$ Ibid, 8.

${ }^{62} \mathrm{Ibid}, 7$; the origin of the quotation used is found in the notes-section of Mitchell and Kramer's monograph, page 325 .

${ }^{63}$ Ibid, $2,13$.

${ }^{64}$ Ibid, 23-24, 26, 34.

${ }^{65}$ Ibid, 70.
} 
millionaires, and implicitly, that the business owners lot in life was a result of hard work and virtue - which the strikers wanted to unethically possess. ${ }^{66}$ The idea of maintaining a static image of the strikers, and controlling the imagery of the strike outside of Winnipeg to the Canadian government and the public, as well as what the CC1000 meant to the city of Winnipeg, were, Mitchell and Kramer find, well-worked goals. Continually, the CC1000 iterated notions that they were integral in providing order of utilities and necessities and only 'true' British were anti-striker's. ${ }^{67}$

A recurring theme throughout When the State Trembles is the discovery of the important influence that Andrews had in the strike. Using newer archival material, the general sentiment established in the previous historians perspective on the topic that the government responded with an 'iron fist in a velvet glove' towards the strikers is misleading. Instead, Mitchell and Kramer find Andrews was really a "Machiavellian" figure through out the strike and Arthur Meighen, the 'prince.' The lawyer Andrews, expert in persuasion, continually misinformed Meighen when it came to the events of the strike, such as, the overwhelming support of returning Veterans to the CC1000's cause - which there was not [for the most part], or the imagery that the strikers were becoming violent - which to an extent they were not, or that there was an optimism in Winnipeg that the strike would soon be over-there was not really any reliable way to surmise this. ${ }^{68}$ Instead, Meighen and Ottawa received the CC1000's framed-version of events, a specific image that resulted in the federal government's confusion on how to manage the events that led to Andrews' and the CC1000's advice as being more than simply considered, more often that not it was blindly, though hesitantly, followed. Mitchell and Kramer's analysis reveal that some of the controversial decisions related to the strike, such as, amendments made to the Immigration Act due to the 'need' to deport influential strikers, and the dismantling of an arbitration group because of the arrival of Gideon Robinson were related to Andrew's will, not Meighen's — who historically became associated with these issues. ${ }^{69}$

Also, Mitchell and Reinhold place emphasis on a riot that occurred on 10 June 1919 as pivotal from Andrew's perspective. ${ }^{70}$ For Andrews, this may have been the proverbial 'straw that broke the camel's back' because it facilitated the CC1000's constructed narrative of revolution in Winnipeg, and, in weeks, striker subordination occurred when strike leaders were arrested, and ultimately the strike ended.

\section{Analyzing the Winnipeg Strike Historians: New Perspectives and Old}

In the past 60 years, the historiography of the general strike in Winnipeg is a prime example of the way that perspectives on historical events, in general, shift through scholarly literature. But what accounts for this shift? For one, new interpretations result from the availability of new sources surrounding the topic. Clearly this is demonstrated in Mitchell and Kramer's monograph, but also from Bercuson too. Bercuson's use of archival sources such as letters, and telegrams largely set him apart from Master's who used mainly newspapers for The Winnipeg General Strike. Moreover, we also find that the availability of new sources on a topic facilitates

\footnotetext{
${ }^{66}$ Ibid, 31.

${ }^{67}$ Ibid, 124-130

${ }^{68}$ Ibid, 106, 110, 113, 115, 141-142.

${ }^{69}$ Ibid, 131-132, 146, 147.

${ }^{70}$ Ibid, 123.
} 
earlier historical points with new evidence to support their assertions that ultimately propel the historiography on a topic too. Certainly this is the case considering what Gerald Friesen finds in 'Bob Russell's Political Thought: Socialism and Industrial Unionism in Winnipeg, 1914 to 1919.' The essay deals largely on the idea the Bob Russell, a significant member of the WGS didn't want to participate in - or for the matter thought that the strike was conducive to the socialist cause being organized by the One Big Union. ${ }^{71}$ Instead the strike was viewed as a worker anomaly that appeared too quick, too ill prepared, and ultimately undermined what the OBU were attempting to establish in Canada for workers. Within the literature, dating back to the seminal study by Masters, the perspective of Bob Russell not actually wanting to participate in the strike existed, but not to the extent that Friesen finds in his essay forty-five years later. Master's monograph is a peculiar case in the historiography of the Winnipeg General Strike because he wrote it far before the emergence of social/labour historians in the 1970s. Without a 'guide' he developed a monograph that largely became ignored by later historians save a point here or there, and given the historical 'tools' that the labour historians possessed twenty years later this is understandable.

In 1973, Penner suggest that "seldom [has the historical community examined] the impact the working class has had on the general political development and political culture of Canada" and that the idea first posited by Masters that the WGS "was one of the major battles that Canadian labour has had ... to establish its trade union rights" has generally been accepted in the historical community as where the historical perspective of the WGS ends. ${ }^{72}$ Paradoxically, Penner's recognized how significant Master's evaluation was for over twenty years but ignores the monograph at the same time. Penner disregards Master's own efforts at implicating the WGS into the larger context of Canada with his 'Reconstruction Chapter' of his monograph that included mention of the Robson Commission, the repeal of Section 98, the amendment to Section 138, or the long-term effect of J.S Woodsworth's popularity. ${ }^{73}$ There was a conscious effort by Masters to include long-term ramifications of the WGS, the impact the working class had on the general political development and political culture of Canada, and contextualize its importance in his contemporary society. The perspective that Masters took with Winnipeg General Strike had its origins ten years before his monograph was published. Master attended an informal meeting in summer of 1940 called by Canadian Historian Arthur Lower. ${ }^{74}$ Lower was dismayed at the idea that in Canada there was a fundamental disconnect between the histories written by Canadian historians and the country. As historian George Brown surmised in 1941, taking cue from Lower: "we [historians] have dealt with more specialized aspects of a subject, and have not dealt with the more fundamental assumptions of the society we live." ${ }^{, 75}$ When one takes into context this element and compare it with Master's seminal study in the WGS we see the trend emerge within The Winnipeg General Strike that sought to contextualize the event politically, and as well as apply it to contemporary society.

\footnotetext{
${ }^{71}$ Friesen, Gerald. River Road: Essays on Manitoba and Prairie History [Winnipeg: University of Manitoba Press, 1996], 121-146.

${ }^{72}$ Introduction of Norman Penner's Winnipeg 1919: The Strikers' own History of the Winnipeg General Strike [Toronto: James, Lewis \& Samuel, 1973], xi.

${ }^{73}$ Masters, Winnipeg General Strike, 135-150.

${ }^{74}$ Donald Wright, The Professionalization of History in English Canada [Toronto, Buffalo, and London: University of Toronto Press, 2005], 150.

${ }^{75}$ Ibid, 151.
} 
As new historians have taken on the WGS, with 'new' perspectives applied, and new archival material available, by and large, Masters' contributions and his seminal work became overlooked. However, this is not without some of validation. For instance, Masters treats the CC1000's newspaper as a legitimate source to demonstrate the fear of bolshevism while Mitchell's later perspective in When the State Trembled indicates that the newspaper was used in a propaganda-like way. ${ }^{76}$ This reflects a later movement within the historical community that does not take primary sources from a period at 'face-value' and instead scrutinizes the context of the sources to draw a sharper interpretation of the history examined. Also, some of the secondary sources that Masters uses in his monograph are largely general in scope and leads Masters to make hasty assumptions, such as when he wrote, "the history of the trade union movement will indicate that until 1914 it had remained comparatively mild and orthodox." 77 While this may be true to an extent it limits Masters in the sense that it does not recognize that the workers who identified with trade unions were generally stigmatized in the industry by employers, thus the relationship between the employee and the employer in Winnipeg fell out of this realm. Bercuson finds this trend in his study of Confrontation at Winnipeg.

A main theme of Bercuson's work is an emphasis that the Winnipeg General Strike was a result of working class discontent, generally, in Western Canada and specifically in Winnipeg. Simply, Bercuson's interest in addressing the WGS in a monograph can be placed in the overarching 'tone' of his contemporary when in the mid-1960's Ramsey Cook and J.M.S Careless emphasized that historians should pay "greater attention ... [to] 'limited identities' of regions and provinces and the distinct worlds of working people."78 Certainly the connection can be made that correlates this trend in the Canadian historical community to the perspectives in Bercuson's Confrontation at Winnipeg. However, this somewhat ignores the individual history of Bercuson. Bercuson's interest in the topic of the working class was also partly due to his own social upbringing of "low to middle class" and that the atmosphere in Quebec during the 1960s, that is, the Quiet Revolution. ${ }^{79}$ Possibly, the Quiet Revolution evident in Quebec in the 1960's inspired Bercuson to review further back into historical record of Winnipeg. In Confrontation at Winnipeg there is an emphasis that the city's entire history as an industrial town resulted in the Winnipeg General Strike. Bercuson, who was born in Montreal in 1945, and graduated in 1967 at the Sir George Williams University in the city, was influenced by the "lefty activities" going on in Montreal, such as "rallies for the liberal government, and Rene Levesque." increasing the legitimacy to impose nationalist reforms by the Lesage government in the 1960's, and the Quiet Revolution, was the provincial argument that the history of francophone worker entailed continual subordination to external influences since industrialization and that these features ripened the need for change, in Quebec's case: nationalization of industry. ${ }^{81} \mathrm{We}$ find similar elements of Bercuson's argument that the events that precipitated the WGS had its

\footnotetext{
${ }^{76}$ For an exhaustive list of propaganda employed by the $\mathrm{CC} 1000$ and Andrew in Kramer and Mitchells monograph see category: 'Citizens' Committee of One- Thousand [Winnipeg]', subcategory 'propaganda' in Index of When the State Trembled, 428.

${ }_{77}^{77}$ Masters, Winnipeg General Strike, 5.

${ }^{78}$ Carl Berger, ed., Contemporary Approaches to Canadian History, [Toronto: Copp Clark Pitman Ltd., 1987], 1.

${ }^{79}$ David Jay Bercuson, interview by Trevor Stace, Edmonton Alberta, November 25, 2012.

${ }^{80}$ David Jay Bercuson, telephone interview by Trevor Stace, Alberta, November 25, 2012.

${ }^{81}$ The intellectual arguments that detail the way that the history of Quebec was interpreted in Quebec are found in Ronald Rudin's Making History in Twentieth Century Quebec [Toronto, Buffalo, \& London: University of Toronto Press].
} 
beginning since Winnipeg became an industrial center, and that the Winnipeg General Strike-in a similar 'thread' to the way the population tried to gain control in the economy in Quebec through the Quiet Revolution — was an attempt at establishing working class influence in the industry. ${ }^{82}$ The marked history of worker suppression is evident with the details the Bercuson provides about the city of Winnipeg's employer-employer history, as well as worker interaction with the province's government.

However, Heron perceives that instead of contextualizing the WGS as a function of the microanalysis of the history of the city, it is better understood within Canadian history as a component to an encompassing theme of a national working class revolt in Canada from 1917 to 1925. As such, Workers Revolt in Canada emphasizes the national situation in Canada that facilitated working class discontent. Heron uses the emphasis on the strike in Winnipeg General Strike by previous historians to redirect the focus into the perspective that working class revolt existed in all across Canada. From the national perspective developed by editor Heron, as well his suggestion that ethnicity and gender are less accounted for in the history of the revolt, he tasks Mitchell and Naylor to target the events of the Winnipeg General Strike. However, when reviewing Bercuson's monograph, and to some extent Masters, on the strike; the idea that the national perspective, ethnic perspective, and women's role are largely missing is unfounded.

Bercuson, identifies the culmination of factors at the federal, provincial, and local level to extract a synthesis of the interplay of events that resulted in the WGS. Moreover, a conceptualization of the Winnipeg General Strike in terms of a direct function to the national policies of the Dominion government put in place during the war does not adequately account for the marked difference in results in Winnipeg compared to the rest. Certainly other variables need to be highlighted in an effort to understand why events played out the way they did but the variables do not simply start with the Great War, it's too specific, and discounts for the overall atmosphere established in a city previous to that. Moreover, placing the perspective that the pre-Great War variables within specific localities mattered just as much as the variables during the Great War any synthesis that might be done in studies other than Winnipeg, as Heron tasks historians to undertake, will undoubtedly underestimate the importance of micro-variables and thus provide an inadequate account. In the way that the 'atmosphere' in Winnipeg contributed to the radicalism that occurred in 1919, it is possible that other localities, and their working class history that predates the Great War watershed affected their own regional manifestation. In some sense, Heron's over-arching theme somewhat follows a Master's approach to the WGS where a watershed is defined and anything before the watershed did not matter; Master's reached the same conclusion that Heron did in the sense that he concluded that since the history of the trade union movement was mild and orthodox previous to 1914 is should largely be discounted. Bercuson, in this writer's opinion provides enough evidence to validly question the 'water-shed'approach that Masters and Heron endorse. It is too general to conceptualize the history of Canadian workers in terms of a national awareness of working class consciousness, instead, a sharper interpretation that each region/city had its own particular set of circumstance, and while the Great War should be considered amongst the variety of factors present it certainly should not be an over-riding theme. Bercuson, using a non-nationalist approach, operates quite effectively in this sense and Confrontation at Winnipeg offers a well-made outline in terms of approaching working class history in other areas during this period in Canadian history. This is not to say that

\footnotetext{
${ }^{82}$ Bercuson, Confrontation at Winnipeg, 1-30.
} 
the 'call to arms' to document, by Heron, other working class history during this time period is not lost on this writer, this is also important. What is also important are the steps taken by Mitchell and Naylor that considered the approach to WGS in terms of a top-to-bottom perspective - or as I have noted before, a middle-to-top-to-bottom perspective.

When the State Trembled marks the final addition to the historiography of Winnipeg in terms of a look back in 2012. It truly is a reflection of a monograph that directly functions as a result of their access to primary sources and provides new information and content to the topic. When looking at the notes in When the State Trembled, the sources that Mitchell and Kramer use for their monograph are largely from archived documents that became accessible in 1987/88. With the focus on the CC1000's efforts at propaganda, we see the way that the historiography has come a long way from accepting the newspapers as reflective of a true political stance on the WGS, like Masters did, into the conception that the efforts of the CC1000 were specifically framed to delegitimize the worker's cause. We also see how access to primary documents like those regarding the CC1000 can spawn an entire monograph - certainly commendable considering that the origins of the historiography on the $\mathrm{CC} 100$ began with an off-handed remark by Masters who wrote in the 1950's: "the citizens' committee was theoretically neutral, [yet] in practice it was opposed to the strike. ${ }^{, 83}$ Moreover, the new primary source provides emphasis on a largely forgotten group that existed in Winnipeg and re-directs the entire focus of the WGS historiography that had been squarely on the strikers for sixty years. Moreover, instead of getting involved in the largely circular argument - as I hope that I have demonstrated - whether or not that the history of the strike was a function of the Great War-first posited by Masters, and repackaged by Heron sixty years later, or if it was a result of industrial worker discontent that had its origins since the beginnings of industrialization like Bercuson suggests, Mitchell and Kramer find sources that contributed to the overall understanding of what happened in the strike by showing the history opposite the workers, the history of A.J Andrews and the CC1000.

Given lack of access to documents, it is forgivable that previous studies into the Winnipeg General Strike have characterized the Dominion government, and Arthur Meighen, as playing a large part in the decision-making process of what to do in Winnipeg. According to Mitchell and Kramer, the Dominion government and Meighen were continually misinformed on the situation in Winnipeg and as a result made decisions based off these facts. In this way the government, then, has a proverbial 'scapegoat' when it comes to the history of Winnipeg General Strike. And, reflecting for a moment on Mitchell and Kramer's findings, and the way that an official federal recognition in any future centennial celebrations of the Winnipeg General Strike in 2019 may have been 'awkward' due to their own role in the historical event previous to Mitchell and Kramer finding out what they did about the relationship between Meighen and Andrews; the findings from the historians may facilitate the ability of the Federal Government of Canada to publically recognize the event in the future since they too were victims, in a way, at the hands of Andrews and the continual misinformation he provided to the Dominion Government.

\section{Conclusion}

In summary, the sixty years of academic writing on the history of the Winnipeg General Strikes have yielded some interesting features. From the mid-twentieth to early twenty-first century,

\footnotetext{
${ }^{83}$ Masters, The Winnipeg General Strike, 65.
} 
from a progressive-perspective we find the history on the topic becomes increasingly sharper as the access to primary sources and theoretical perspectives becomes larger. However, this is not to suggest that the history on a topic follows a progression where the importance of one person's work is more important that preceded it. Rather, when looking into the historiography we find features of the historical writing that are a function of their contemporary. Master's contemporary encouraged a sense of contextualization of historical issues into the present; Bercuson's facilitated a perspective that looked back into the beginnings of industrial situation in Winnipeg to notice a trend to the 'inevitable' confrontation at Winnipeg; Heron's contemporary influences centralized that a marked lack of recognition of other working class phenomenon in Canada was present and that a workers' revolt in Canada, from 1917-1925, existed and needed to be emphasized; and finally, Mitchell and Kramer's contemporary influenced them because it provided them with access to material previously not accessible, and approaches [like a top-tobottom] previously not incorporated on the WGS. Indeed the scholarly historiography of the Winnipeg General Strike has propelled the perspectives in new ways, but also to some extent has gone full circle.

\section{Bibliography}

\section{Primary Sources}

Anonymous. "The Scars Fade Slowly." Winnipeg Free Press, June 21, 2009.

http://login.ezproxy.library.ualberta.ca/login?url=http://search.proquest.com.login.ezproxy. library.ualberta.ca/docview/752229481? accountid $=14474$ [accessed November 2012].

Legislative Assembly of Manitoba. "Thursday May 12, 1994."

http://www.gov.mb.ca/legislature/hansard/5th-35th/vol_26.html [accessed November 2012].

The Manitoba Historical Society. "Winnipeg General Strike, $50^{\text {th }}$ Anniversary Plaque." Historic Sites of Manitoba: Commemorative Plaques of the Winnipeg City Hall. http://www.mhs.mb.ca/docs/sites/cityhallplaques.shtml [accessed November 2012].

University of Winnipeg Faculty Association. "90 ${ }^{\text {th }}$ Anniversary of the 1919 Winnipeg General Strike.” UWFA News-May 2009. http://www.uwfa.ca/index/2009/5/26/90th-anniversaryof-the-1919-winnipeg-general-strike.html [accessed November 2012].

\section{Secondary Sources}

Bercuson, David J. Confrontation at Winnipeg: Labour, Industrial Relations, and the General Strike. Montreal and London: McGill—Queen's University Press, 1974.

Berger, Carl, ed. Contemporary Approaches to Canadian History. Toronto: Copp Clark Pitman Limited, 1987.

Friesan, Gerald. River Road: Essays on Manitoba and Prairie History. Winnipeg: University of Manitoba Press, 1996.

Heron, Craig, ed. The Workers' Revolt in Canada, 1917-1925. Toronto, Buffalo, and London: University of Toronto Press, 1998. 
Masters, D.C. The Winnipeg General Strike. Toronto: University of Toronto Press, 1950.

Mitchell, Tom and Reinhold Kramer. When the State Trembled: How A.J Andrews and the Citizens' Committee Broke the Winnipeg General Strike. Toronto, Buffalo, and London: University of Toronto Press, 2010.

Penner, Norman. Winnipeg 1919: The Strikers' own History of the Winnipeg General Strike. Toronto: James, Lewis, \& Samuel, 1973.

The Manitoba Historical Society. "Timelinks: Citizens' Committee of 1000.” http://www.mhs.mb.ca/docs/features/timelinks/reference/db0121.shtml [accessed November 2012].

---. "Timelinks: The Western Labour News." http://www.mhs.mb.ca/docs/features/timelinks/reference/db0063.shtml [accessed November 2012].

Wright, Donald. The Professionalization of History in English Canada. Toronto, Buffalo, and London: University of Toronto Press, 2005. 